THE ONE AND THE MANY 



\section{THE ONE AND THE MANY}

Contemporary Collaborative Art in a Global Context

Grant H. Kester 
() 2011 Duke University Press

All rights reserved

Printed in the United States of America on acid-free paper @ Designed by Heather Hensley

Typeset in Warnock Pro by Tseng Information Systems, Inc.

Library of Congress Cataloging-in-Publication Data appear on the last printed page of this book.

Duke University Press gratefully acknowledges the support provided through the Arts and Humanities Innovation Fund and the Office of the Dean of Arts and Humanities at the University of California, San Diego, and the Creative Capital | Andy Warhol Foundation Arts Writers Grant Program, which provided funds toward the production of this book. 
To Samira Kester, my collaborator in life 